УДК: $7.033(4)$

ББК: 85.143

A43

DOI: $10.18688 / \mathrm{aa} 177-3-35$

Marco D’Attanasio

\title{
The Frescoes in San Lorenzo al Lago in Fiastra and the Sermo Rusticus in the Painting of the Southern Marches
}

The church of San Lorenzo al Lago in Fiastra, a small village in the region of Marches, central Italy, preserves an interesting cycle of frescoes. We have little information about the origin of the church: the first time that it is mentioned is in a document dated to the first half of the $14^{\text {th }}$ century which is a copy of some documents from the first half of the $13^{\text {th }}$ century ${ }^{1}$.

The architectural plan of the church is the result of subsequent construction phases. The building of the $13^{\text {th }}$ century was very simple: a single nave covered with a pointed barrel vault in the first two bays ${ }^{2}$, and the presbytery, divided by a triumphal arch, covered by a groin vault, with a semicircular apse. Following this phase two aisles were $\operatorname{added}^{3}$ (Fig. 1).

In the $16^{\text {th }}$ century, a new church was built against the left side of the building which incorporated the left aisle, as the plugged arches prove ${ }^{4}$.

In the past the frescoes might have decorated all the walls; today they are preserved only on the right wall of the nave, on the both sides of the triumphal arch, on the left wall of the choir and in the apsidal arch.

\footnotetext{
1 I am very grateful to Prof. Alessandro Tomei, Prof. Pio Francesco Pistilli and Prof. Gaetano Curzi for helping me to reconstruct the architectural phases of the church. The photos of the frescoes of San Lorenzo al Lago are courtesy of Arcidiocesi di Camerino-San Severino Marche, Ufficio Beni Culturali Ecclesiastici.

The document concerns an exchange of plots of lands located between Acquacanina and Fiastra and it is signed by Giberto, Corrado, Offreduccio from Falerone and Finaguerra di Leone. In the list of the lands plots are mentioned some properties neighbouring with "terra ecclesie sancti Laurentii". The second part of the document is a list of the lords of Acquacanina and Bolognola that swear to Giberto and Corrado. Among the witnesses of the oath there is a "donno Salimbene preposito Sancti Laurentii" [17, pp. 150, 155]. The "ecclesie S. Laurentii de Flastra" is also mentioned in the Relationes decimarum of the years 1299-1300 [23, no. 5287 p. 455].

2 This part of the building is architecturally very similar to the Oratory of St. Pilgrim in Bominaco in the Abruzzi.

3 Today only the right aisle is preserved, its size is very small, therefore it was probably a simple corridor for practical uses. It is also possible that the two corridors were present since the beginning, and the connection with the nave was either absent or made with small passages. The present arches break the painted decoration, assuring that they are the result of an architectural transformation.

4 It is impossible to know if the length of the two aisles was the same of the first two bays or if they continued till the presbytery. In this second case, it is possible that a passage between the presbytery and the aisle was already present, and it was enlarged during the restoration works of the $16^{\text {th }}$ century. On the right side an arch connects the church with the sacristy. Other buildings are on this side, so it has been supposed that there was a monastery where regular canons lived [5, p. 193].
} 


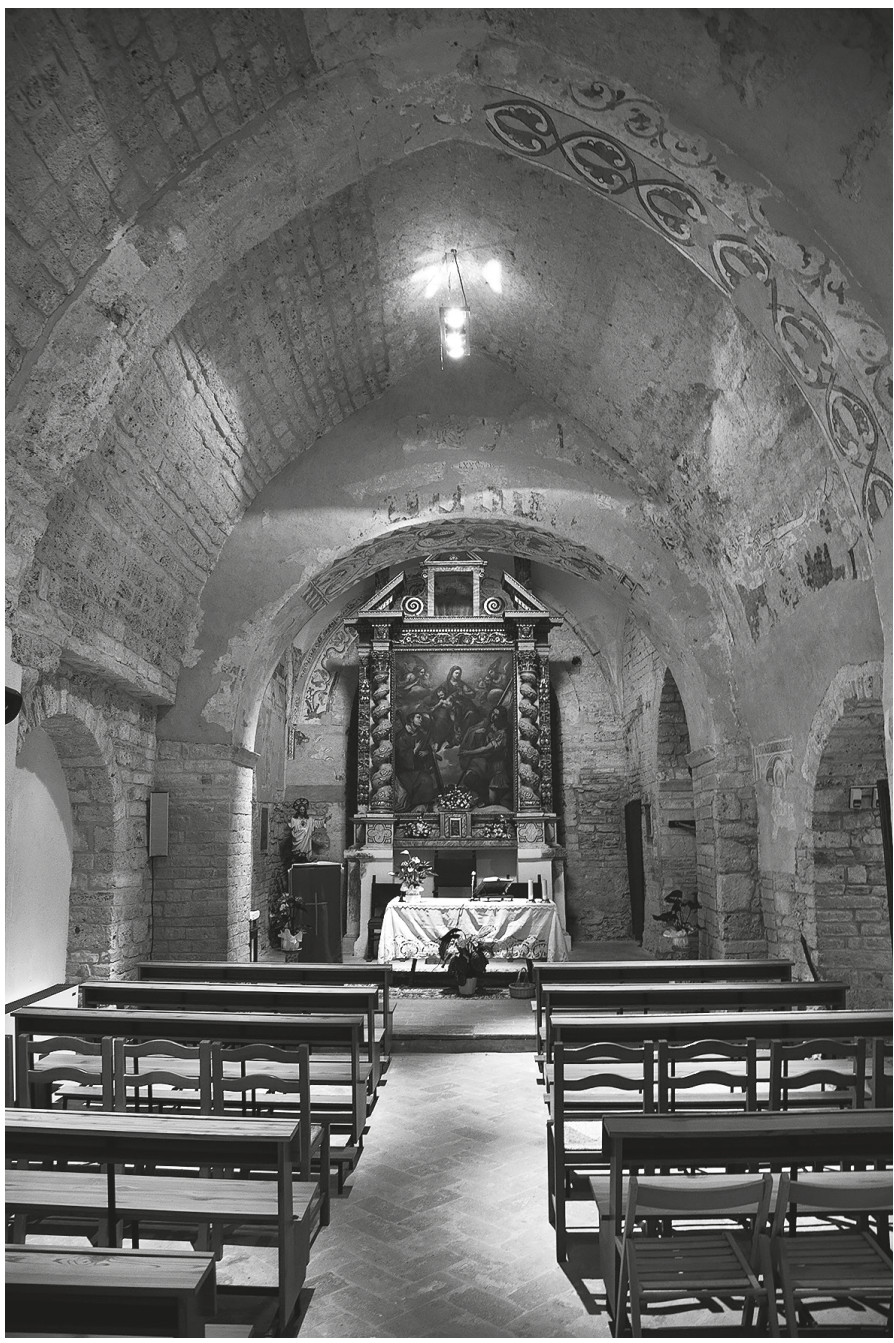

Fig. 1. Interior of the church. $13^{\text {th }}$ century, San Lorenzo al Lago, Fiastra

The paintings were discovered during the restoration works of between 1960s and the 1970s; but they have practically been neglected by art historical literature till today ${ }^{5}$.

5 The first mentions, following the restoration works, are very brief. Giuseppe Vitalini Sacconi says that the paintings show a Romanesque-Byzantine style derived from Spoleto, later he will date the frescoes to the $12^{\text {th }}$ century [25, p. 222, n. 88; 26, p. 15]. Giacomo Boccanera tried to identify the iconographies of the painted scenes [2, p.7]. This iconographic and iconological study was used by Pietro Zampetti, who also linked the frescoes to the late-Romanesque style present in Spoleto [31]. Pietro Zampetti examined more in depth the paintings of San Lorenzo al Lago in his famous monograph Pittura nelle Marche; he recognized the episodes of the life of Christ and remarked iconographic affinities with the frescoes in the church of Santa Maria ad Cryptas in Fossa, in the Italian region of Abruzzi. From a stylistic point of view it is possible to see a connection with the Virgin leading Christ to school, the Annun- 


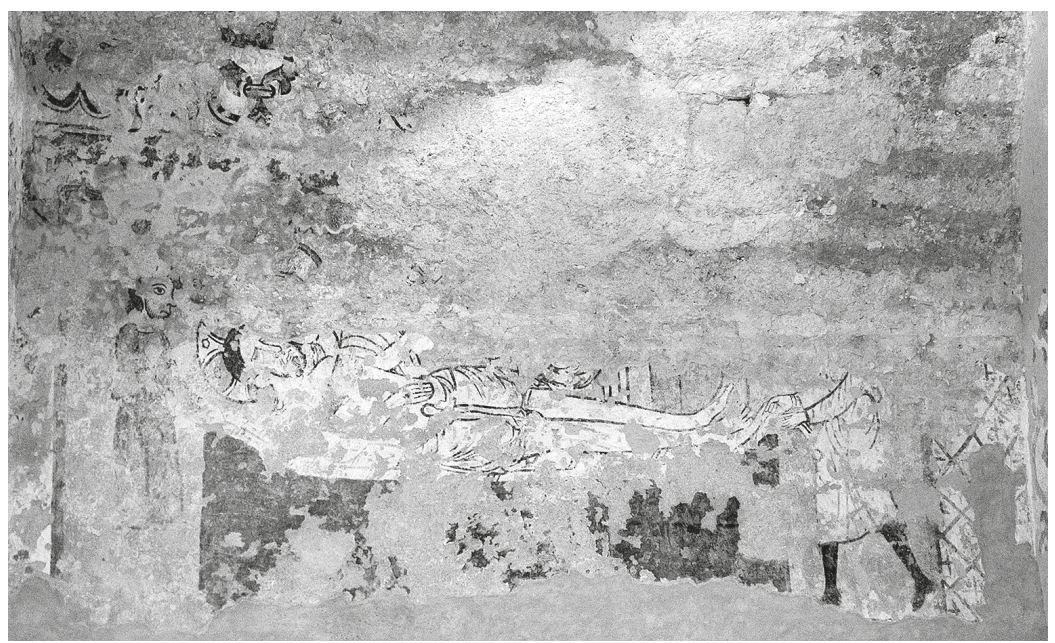

Fig. 2. Entombment of Christ. 1275, San Lorenzo al Lago, Fiastra

The episodes which survived make us say that the main theme is the Passion of Christ. It is very likely that the history started on the left wall of the first bay - or else, in the second bay for the reasons that I will explain later - and continued towards the presbytery and then on the right wall in the direction of the counter-façade.

Now, we can start the description following the Christological cycle: Christ carrying the cross and the Crucifixion are depicted on the lower tier of the left wall of the choir.

The episode in the upper tier was never recognized due to the bad state of preservation. I presume that it represents the Martyrdom of saint Lawrence, with the saint lying on the gridiron engulfed in flames ${ }^{6}$. Probably this story was painted in this position to create a typological parallelism between the supreme sacrifice of God's Son and the sacrifice of the dedicatory Saint of the church (Ill. 80).

In the apsidal arch an enthroned Virgin with Child is painted along with a dragon spitting up a raceme with red, white and blue flowers.

Due to the loss of the frescoes on the right wall of the choir, the story continues on the same wall of the nave with the Entombment of Christ (Fig. 2); we can suppose that the previous lost episode represented the Deposition from the Cross ${ }^{7}$.

ciation and the Last Supper painted in the church of San Vittore in Ascoli Piceno; last but not least he mentioned the painted inscription on the triumphal arch with the letters LXXV, realistically the date when the frescoes were executed: 1275 [30, pp.67-68; 32, pp.60-61]. Simona Manacorda affirms that a deep formal influence from the art beyond the Alps is present in the frescoes [12, p. 196], and Corrado Fratini compares the paintings with the mural in San Prospero in Perugia [9, p. 26]. The last study on San Lorenzo al Lago is an iconographic and iconological analysis made by Paolo Cruciani [5, pp. 193-199].

6 None of the episodes of the life of Christ that precede the Crucifixion are connected with the fire, and I doubt that it could be a scene from the Old Testament because there is no correlation with other painted episodes.

7 On the left wall of the choir the episodes are arranged in two tiers, therefore it is possible that the same composition was adopted on the opposite wall. If in the lower tier the Deposition from the cross was represented, in the upper tier there was probably an episode of the life of Saint Lawrence after the Martyrdom. The story of the saint continues 
In the first bay, the Christological scenes are abandoned in favour of an eschatological theme (Pl.2). The Patriarchs with the souls in their bosoms, Saint Peter who opens the Paradise's door and the multitude of the righteous are evident references to the afterlife ${ }^{8}$. Unfortunately, the loss of the frescoes on the opposite wall and in the counter-façade - except for a huge St. Christopher - makes the iconographic reconstruction harder. The themes that can be seen today could have been part of a Universal Judgement [12, p. 196] or a vision of the Afterlife $[1$, p. 404], similarly to a case in the Oratory of St. Pilgrim in Bominaco, whose frescoes date back to 1263. The frescoes in Fiastra, moreover, share the same position of St. Christopher in the counter-façade with those in the Abruzzi. It would not be wrong to suppose that, following the Abruzzese model, an infernal vision was painted on the left wall of the first bay. If it were so, the Christological cycle would have started in the next bay and, as this would have been the only useful wall before the episodes of Christ carrying the cross and the Crucifixion, we could certainly affirm that the church had only the history of the Passion of Christ because there was no room for the previous Christological episodes.

On the side of the triumphal arch towards the apse a mandorla sustained by an angel is painted, but we cannot know what was represented there because the window opened during the restoration in the $16^{\text {th }}$ century destroyed that part of the paintings. Probably there was an Ascension or another majestic representation.

The intrados of the arch is decorated with big red flowers inscribed within leaves (Fig.3), under the imposts there are two panels: on the left there is a crowned woman with nimbus, perhaps the Virgin Mary and, on the opposite side, there is the episode of the Noli me tangere, with Christ and Mary Magdalene.

On the triumphal arch, on the side toward the nave, there is a clypeus sustained by an angel, and underneath we find a fragmentary painted inscription with a date, 1275 (Fig. 3). This is very important because it certainly refers to the year when the mural decoration was accomplished.

The ornamental motifs used as borders for the walls or for the episodes are numerous and give unity to the whole decoration.

Only in the first bay the painted base is preserved. It is composed by a velarium and a band with animals facing each other: a bear, a red lion, and a dog or perhaps a panther; each couple of beasts is divided by a little tree ${ }^{9}$ (Ill. 81).

From a stylistic point of view it is very important to highlight the austerity of the means of expression. The colour range is limited to yellow - especially used for the background - red, black, white, and the pigment that is spread in a compact way with no chiaroscuro. Characters and objects are drawn with a synthetic line that marks the border and drafts the details. The fac-

with the Transport of the body - this episode, for example, was represented in the lost frescoes of Saint Lawrence's life in the counter facade of the Basilica of Saint Lawrence outside the Walls in Rome [18, p. 256] — and the Burial. This last episode, if present, would realize another typological parallelism with the Deposition from the cross and, more convincing, with the Entombment of Christ.

8 I disagree with Pietro Zampetti and Paolo Cruciani who identify the scene represented on this wall with the Harrowing of Hell [5, pp. 197-199; 32, p. 60].

9 The band with the animals continued in the second bay too, as the painted fragment of a tree near the passage between nave and aisle proves. It stopped near the triumphal arch: at the bottom of the band there is an unidentifiable silhouette, maybe a man chest, surely not recognizable as an animal. 


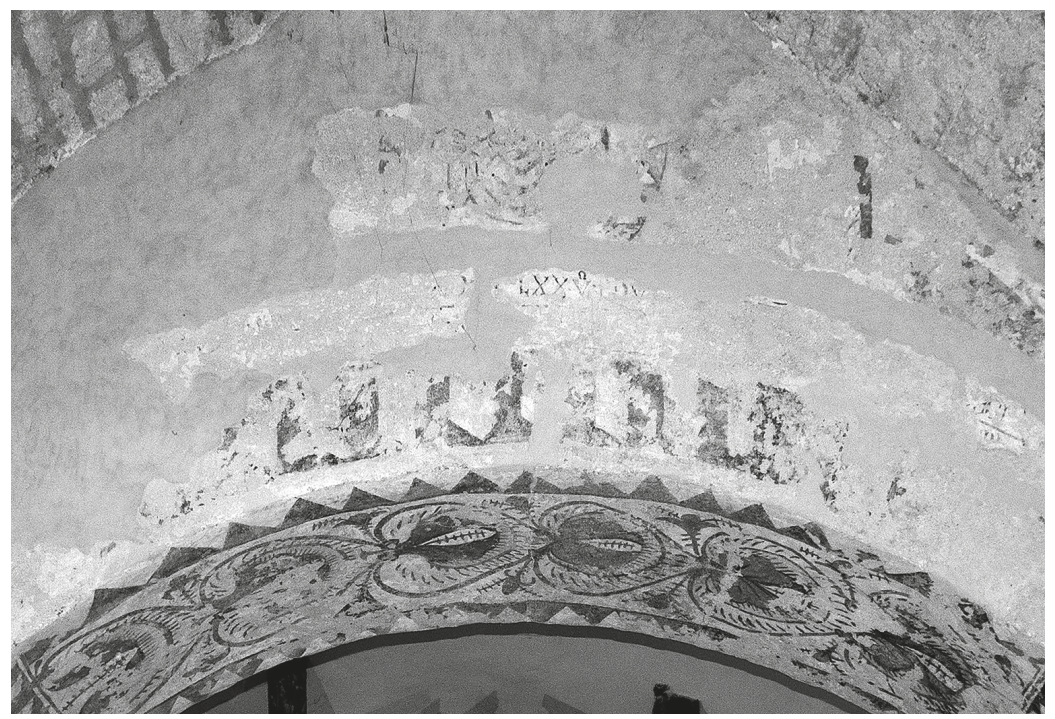

Fig. 3. Inscription with the dating. 1275, San Lorenzo al Lago, Fiastra

es have very distinctive features and there are no attempts to build a three-dimensional space. The characters seem to fluctuate in the space that is represented with few essential elements.

The sources of this simple figurative language could be traced in the coeval painting in Perugia. More exactly in those frescoes characterized by a sermo rusticus, as Scarpellini called it, a language - and I quote - "concise and basically graphic, that takes by the style of the more noble art the fundamental features" [21, p. 95].

It is important to notice that in this text the term sermo rusticus is used in a critical sense, as done by Pietro Scarpellini. This is not a judgement of quality; in fact the frescoes are very elegant and well done, despite their stylistic simplicity. The painters deliberately chose to use this artistic language that represented an alternative to the Byzantine manner commonly used in central Italy.

Pietro Scarpellini used the term sermo rusticus to describe the frescoes in the church of San Bevignate in Perugia, dated back to the $1270 \mathrm{~s}^{10}$. In my opinion, these paintings have a lot in common with San Lorenzo al Lago from a stylistic point of view ${ }^{11}$, and even the dating is very similar.

In the church in Perugia the frescoes cover every wall ${ }^{12}$; the style is very homogeneous although they were painted by different artists who, in order to complete the decoration in a short time, used to alternate on the scaffolding [6, p. 49; 22, pp. 210-211].

10 In 1262 Bonvicino asked to the canons of the Cathedral of Perugia a marble plaque, maybe to use this as an altar table $[21$, p. $98 ; 22$, p. 210].

11 For me the comparison proposed by Corrado Fratini with the mural paintings in San Prospero in Perugia $[9$, p. 26] is acceptable only for the reference to the sermo rusticus, in fact these frescoes appear more rustic than those in San Lorenzo al Lago.

12 For a complete description of the mural decoration with images see the study of Pietro Scarpellini [21, pp.97$132]$. 
In San Lorenzo al Lago and in San Bevignate we can find the same decorative system: the red circular polka dots stamped on the yellow background, the painted building bricks, the borders with triangles, the big disks with flowers with lanceolate petals and the shoots in bloom. Also the characters show unquestionable affinities: there is a close bond between the face of the Christ in the Last Judgement in San Bevignate and the Patriarch Isaac in San Lorenzo, or the righteous of the two cycles.

Another painted cycle that presents stylistic affinities with San Lorenzo is that in Santa Maria di Ancaelle in Sant'Arcangelo, near Perugia, dated back to the seventh or eighth decade of the $13^{\text {th }}$ century ${ }^{13}$.

I would like to propose a comparison between the souls in the Purgatory in Santa Maria di Ancaelle and the souls in the bosom of the Patriarchs.

It is very important to focus the attention on the tier with animals facing each other (Ill. 81). This theme is influenced by the bestiary that spread in the $12^{\text {th }}$ and $13^{\text {th }}$ century [10], and then developed in the wall painting, and frequently in the frescoes in Perugia, as testified by those in San Bevignate or San Giovanni del Fosso.

The bestiary painted in this last church - now a private house - represents real and fantastic animals; among them the panther and the lion are very similar to those in San Lorenzo al Lago. The frescoes in San Giovanni del Fosso were made approximately in 1233 [20]; the dating is for sure very different to the 1275 of the church in the Marches, but the two mural decorations are very close from a stylistic point of view, because in both of them a linear and simple figurative language is present.

Art historians have found some relationship with the paintings beyond the Alps [12, p. 196]; this is a very intriguing hypothesis, because there are particular affinities with the frescoes in the French templar churches.

The sermo rusticus here discussed is a formal peculiarity of the mural decoration of many churches which belonged to the Templars, but it is wrong to believe that every painting involved with this figurative culture is part of the templar world. In fact, the same main characteristics are present in the secular painting realized between $12^{\text {th }}$ and $13^{\text {th }}$ century $[6, \mathrm{pp} .23-89,115-117$.

It is very difficult to affirm that the workshop that painted in San Bevignate was the same as that in San Lorenzo al Lago; the comparisons of figurative parts between the two painted cycles show similarities more or less convincing but never perfect copies, whereas the decorative motifs have much more in common.

For these reasons, I am pretty convinced that some painters in San Lorenzo al Lago were already present in Perugia or, at least, knew those paintings.

This can explain how the sermo rusticus arrived in the Southern Marches; in fact, it is possible to find the same figurative culture in some frescoes in Ascoli Piceno, the most important city of the March of Ancona.

In the church of Saint James there are three panels with St. Michael weighing souls (Fig. 4), an enthroned Madonna with Child and a Saint, which are very similar to the frescoes that we

13 The church bell was cast in 1268 , at the same time maybe the painting decoration of the church was commissioned too [19, pp. 22-25]. 
have just described. They might not have been made by the same artist but certainly they were made in the same period $^{14}$.

More interesting are the three compositions with Christ, from the church of San Vittore ${ }^{15}$, that represent the Virgin leading Christ to school $[27 ; 28 ; 29]$, the Annunciation and the Last Supper (Ill.82). It is easy to find also in these paintings the main characteristics of the sermo rusticus: the colour range limited to white, yellow, red and blue, the absence of perspective and the graphic manner ${ }^{16}$.

Compared to the previous cycles, it is evident that there are the use of a more fluid colour combined in variegated composition, the presence of a chiaroscuro and the dynamism and the grace of the characters. It seems that the sermo rusticus is combined with an emphasised gothic style derived from the art beyond the Alps ${ }^{17}$.

Basing on formal aspects I am persuaded that the three painted compositions from San Vittore were realized few years later than San Lorenzo al Lago, approximately in the 1280 s.

The contiguous panel with the Lamentation of Christ (Fig. 5) seems to be part of the sermo rusticus as well: the colour is flat and the chiaroscuro is absent, the contour line defines only the principal traits with no details and the pose is conventional and stiff.

But, if for the previous artists the sermo rusticus was a

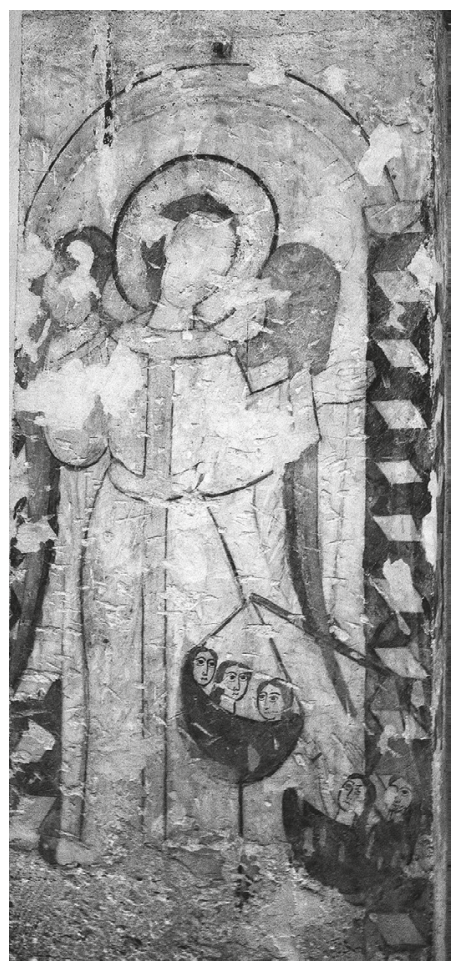

Fig. 4. St. Michael weighing souls. ca. 1270-1280, San Giacomo, Ascoli Piceno deliberated choice to paint, here it seems that it was the result of inability.

14 The three mural paintings have never been studied much due to their bad preservation. Elvira Felci and Franco Laganà dated them to the second half of the $13^{\text {th }}$ century [7, pp. 67-71]. Daniela Ferriani accepted this chronology and proposed that the murals of St. Michael weighing souls and the Enthroned Madonna with Child are similar, but more rustic, to the above-mentioned frescoes in Bominaco and Fossa, while the panel with the Saint is close to a Lamentation of Christ painted in San Vittore [8, pp.64-65]. Emma Simi Varanelli defines them less beautiful than other paintings in San Vittore [24, pp. 373-374], whereas Andrea Marchi - just as Ferriani said - believes that the painter of the Psychostasy is the same of the Lamentation of Christ, and then he painted some murals in the church of Santa Maria Intervineas in Ascoli Piceno. All these frescoes can be dated to the end of the $13^{\text {th }}$ century [13, pp. 18-19]. A similar chronology - 1290-1310 - is proposed by Furio Cappelli [4, p. 131].

15 Due to its bad condition, this portion of mural painting was detached during the restoration works of the end of the 1960s and now is preserved in the Episcopal palace [14, pp. 20-25].

16 Pietro Zampetti had already noticed that the manners of San Lorenzo al Lago paintings and that of three compositions with Christ in San Vittore are similar [32, pp.60-61]. Also, Corrado Fratini called their language similar but, according to him, it is different from that in Fiastra [9, p.26].

17 Gothic stylistic elements on the mural panel from San Vittore have been already recognized by Enrica Neri Lusanna, Emma Simi Varanelli and Furio Cappelli [3, pp. 116-118; 16, p. 168; 24, pp.364-366]. It is also important to remark that in this period in Ascoli Piceno products from France and England were already common, like the little statue of an Angel in the Holy Thorn reliquary in Saint Peter Martyr, and the cope in opus anglicanum donated by Pope Nicholas IV to his birth town [11; 15, pp.33-34]. 


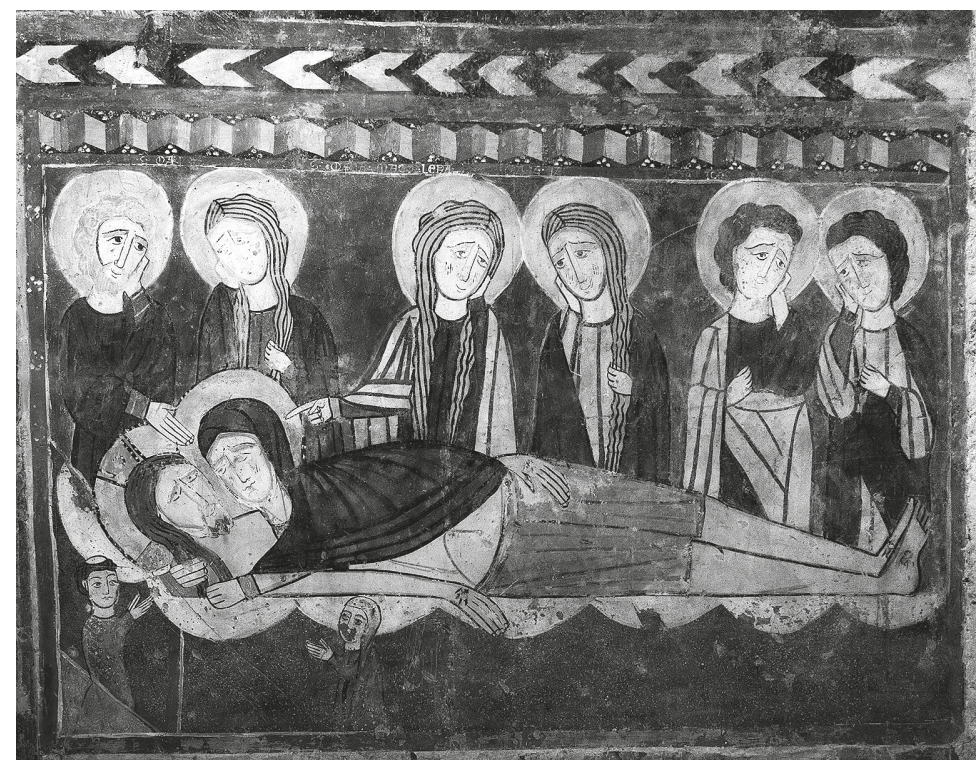

Fig. 5. Lamentation of Christ. ca. 1280-1300, San Vittore, Ascoli Piceno

This panel is painted on the layer different from that of the three Christological scenes, therefore it must be dated after these, probably in the last two decades of the $13^{\text {th }}$ century.

This last painting is in part different from the figurative address expressed by the frescoes in San Lorenzo al Lago and then in the paintings in Saint James and in the three compositions with Christ in San Vittore. But on the whole the murals here discussed show undoubtedly that the sermo rusticus from Umbria is a very important manner of the heterogeneous artistic culture in Southern Marches.

\section{References}

1. Baschet J. Le sein du père. Abraham et la paternité dans l'Occident medieval. Paris, Gallimard Publ., 2000. 413 p. (in French).

2. Boccanera G. Il ciclo pittorico a S. Lorenzo al Lago. Cronache di Provincia, January 1973, p. 7 (in Italian).

3. Cappelli F. Le chiese I. Guida alle chiese romaniche di Ascoli Piceno, citta di travertino. Ascoli Piceno, D’Auria Publ., 2006, pp. 27-120 (in Italian).

4. Cappelli F. Le chiese II. Guida alle chiese romaniche di Ascoli Piceno, città di travertino. Ascoli Piceno, D'Auria Publ., 2006, pp. 121-143 (in Italian).

5. Cruciani P. Storia e arte nella Marca Camerte. Bolognola e l'alta valle del Fiastrone (secc. XII-XIX). Roma, Kappa Publ., 2003. 373 p. (in Italian).

6. Curzi G. La pittura dei Templari. Cinisello Balsamo, Silvana Editoriale Publ., 2002. 141 p. (in Italian).

7. Felci Laganà E.; Laganà F. La chiesa di San Giacomo apostolo in Ascoli Piceno. Ascoli Piceno, D’Auria Publ., 1994. 105 p. (in Italian).

8. Ferriani D. Gli affreschi di S. Giacomo. Il romanico ad Ascoli Piceno. Acquaviva, Fast Edit Publ., 2007, pp. 64-65 (in Italian).

9. Fratini C. Pitture fra Umbria e Marche: primi passi per una storia comparata. Il Maestro di Campodonico. Rapporti artistici fra Umbria e Marche nel Trecento. Fabriano, Cassa di Risparmio di Fabriano e Cupramontana Publ., 1998, pp.12-43 (in Italian). 
10. Grube E. J. Bestiario. Enciclopedia dell'Arte Medievale, vol. 3. Roma, Istituto della Enciclopedia Italiana Publ., 1992, pp. 449-457 (in Italian).

11. Leone de Castris P. Manifattura inglese, ca. 1267-70. Piviale detto "di Niccolò IV". Opere d'arte dalle collezioni di Ascoli Piceno: la Pinacoteca Civica e il Museo Diocesano. Scoperte, ricerche e nuove proposte. Roma, Bozzi Publ., 2012, pp.54-57 (in Italian).

12. Manacorda S. Marche. Pittura. Enciclopedia dell'Arte medievale, vol. 8. Roma, Istituto della Enciclopedia italiana Publ., 1997, pp. 193-199 (in Italian).

13. Marchi A. Pittura medioevale nell'Ascolano e nel Fermano. Beni Artistici. Pittura e scultura. Cinisello Balsamo, Silvana Editoriale Publ., 2003, pp. 13-33 (in Italian).

14. Mazzulani G.; Castellani S. Arte dell'Italia centale dei secoli XIII e XIV. Madonna col Bambino tra due santi, scene del Nuovo Testamento, Madonna con Bambino. Mostra di opere d'arte restaurate, Catalogo della mostra: Urbino, 1969. Urbino, S. T.E. U. Publ., 1969, pp. $20-25$ (in Italian).

15. Montevecchi B. Influssi d'Oltralpe e bizantini tra XIII e XIV secolo. Beni Artistici. Oreficerie. Fermo, Fondazione Cassa di Risparmio di Fermo Publ., 2006, pp. 29-37 (in Italian).

16. Neri Lusanna E. Marche. Pittura murale in Italia. Vol. 1. Dal tardo Duecento ai primi del Quattrocento. Bergamo, Edizioni Bolis Publ., 1995, pp. 168-176 (in Italian).

17. Pagnani G. Terre, vassalli e signori in un documento dellarchivio comunale di Acquacanina nelle Marche della prima metà del secolo XIII. La società rurale marchigiana dal Medioevo al Novecento (Parte prima), Atti del convegno: Ancona, 1974, "Atti e memorie della Deputazione di Storia Patria per le Marche", vol.9, 1975. Ancona, presso la Deputazione di storia patria per le Marche Publ., 1976, pp. 127-167 (in Italian).

18. Queijo K. Le perdute Storie di San Lorenzo sulla controfacciata di San Lorenzo fuori le mura. Il Duecento e la cultura gotica. Milano, Jaca Book Publ., 2012, pp. 255-258 (in Italian).

19. Santanicchia M. Pittura nell'area del lago Trasimeno tra Medioevo e Rinascimento. Storie di pittori tra Perugia e il suo Lago. Morbio Inferiore, Selective Art Edizioni Publ., 2008, pp. 15-74 (in Italian).

20. Scarpellini P. Affreschi duecenteschi nellex chiesa perugina di San Giovanni del Fosso. Scritti in onore di Alessandro Marabottini. Roma, De Luca Publ., 1997, pp. 33-40 (in Italian).

21. Scarpellini P. La chiesa di San Bevignate, i Templari e la pittura perugina del Duecento. Templari e Ospitalieri in Italia. La chiesa di San Bevignate a Perugia. Milano, Electa Publ., 1987, pp. 93-158 (in Italian).

22. Scarpellini P. La decorazione pittorica di San Bevignate e la pittura perugina del Duecento. Milites Templi. Il patrimonio monumentale e artistico dei Templari in Europa, Atti del convegno: Perugia, 2005. Perugia, Volumnia Publ., 2008, pp. 205-284 (in Italian).

23. Sella P. (ed.). Rationes decimarum Italiae nei secoli XIII e XIV.Marchia. Città del Vaticano, Biblioteca Apostolica Vaticana Publ., 1950. 742 p. (in Italian and Latin).

24. Simi Varanelli E. All'origine dell'arte del Duecento italiano: pittura e miniatura al tempo degli ultimi sovrani svevi. Il caso esemplare dei cicli pittorici delle chiese ascolane. Federico II e le Marche, Atti del Convegno di studi: Jesi, 2-4 dicembre 1994. Roma, De Luca Publ., 2000, pp. 325-385 (in Italian).

25. Vitalini Sacconi G. Pittura marchigiana. La scuola camerinese. Macerata, Cassa di Risparmio di Macerata Publ., 1968. 265 p. (in Italian).

26. Vitalini Sacconi G. Macerata e il suo territorio. La Pittura. Macerata, Cassa di Risparmio della provincia di Macerata Publ., 1985. 231 p. (in Italian).

27. Wentzel H. Ad infantiam Christi. Zu der Kindheit Unseres Herren. Das Werk des Künstlers. Studien zur Ikonographie und Formgeschichte. Hubert Schrade zum 60. Geburtstag dargebracht von Kollegen und Schülern. Stuttgart, Kohlhammer Publ., 1960, pp. 134-160 (in German).

28. Wentzel H. Das Jesuskind an der Hand Mariae auf dem Siegel des Burkhard von Winon 1277. Festschrift Hans R. Hahnloser zum 60. Geburtstag 1959. Basel, Birkhäuser Publ., 1961, pp. 251-270 (in German).

29. Wentzel H. Maria mit dem Jesusknaben an der Hand. Ein seltenes deutsches Bildmotiv. Zeitschrift des Deutschen Vereins für Kunstwissenschaft, 1942, vol.9, pp.203-250 (in German).

30. Zampetti P. Arte figurativa nell'alta valle del Chienti tra Medioevo e Rinascimento: aspetti e problemi. Arte e spiritualità nellordine agostiniano e il Convento San Nicola a Tolentino, Atti della seconda sessione del convegno: Tolentino, 1992. Roma, Argos Publ., 1994, pp. 67-75 (in Italian).

31. Zampetti P. Artista tardo romanico. Cristo Pantocratore, raffigurazioni allegoriche e decorazioni. Restauri nelle Marche. Testimonianze acquisti e recuperi, Conferenza Nazionale per la prima relazione sulla situazione ambientale: Urbino, 1973. Urbino, Arti grafiche editoriali Publ., 1973, pp.744-745 (in Italian).

32. Zampetti P. Pittura nelle Marche. Vol. 1. Dalle origini al primo Rinascimento. Firenze, Nardini Publ., 1988. 426 p. (in Italian). 
Title. The Frescoes in San Lorenzo al Lago in Fiastra and the Sermo Rusticus in the Painting of the Southern Marches.

Author. Marco D’Attanasio - Ph. D. University "G. d'Annunzio" Chieti-Pescara, Via dei Vestini 31, 66100 Chieti (CH), Italy. marco.dattanasio@gmail.com

Abstract. The Church of San Lorenzo al Lago, in the village of Fiastra near Camerino, is decorated with an interesting cycle of paintings representing scenes from the Passion of Christ, the Martyrdom of Saint Lawrence and a synthetic view of the Afterlife with the three Patriarchs with the souls in their bosoms; an inscription allows us to date the frescoes to the year 1275 .

The iconographic themes present remarkable peculiarities, linking scenes of the life of Christ with some scenes of the life of Saint Lawrence, the Saint who the church was entitled to, however more attractive is the formal manner showed by the mural.

From a stylistic point of view it is possible to observe the extremely linear simplicity and a colour range limited to black, white, yellow and red.

Until now these frescoes have been practically overlooked by art historical literature. This article presents these unknown paintings and shows how they constitute an important example of pictorial 'sermo rusticus' in the Marches.

The 'sermo rusticus', as Pietro Scarpellini called it, is a pictorial manner characterized by a high stylistic simplicity, and, up to now, it seemed that it was recognizable only in some frescoes in Perugia and its surroundings.

The paintings of San Lorenzo al Lago, in fact, find the most evident stylistic affinities with the murals in the Perugia churches of San Bevignate, Santa Maria di Ancaelle and San Giovanni del Fosso, and, more important, they are the source of inspiration for the fragmentary wall paintings in the Ascoli Piceno churches of San Giacomo, representing Saints and a Nursing Madonna, and the Lamentation of Christ in San Vittore.

Therefore, it is possible to affirm that the pictorial 'sermo rusticus' was not isolated in the Umbria region, but spread also in the Marches, reaching the Adriatic coast, and this allows us to have a wider comprehension of the variety of the pictorial manner present in a border region as the Marches were at the end of the $13^{\text {th }}$ century.

Keywords: San Lorenzo al Lago in Fiastra; Ascoli Piceno; sermo rusticus; painting; Marches, Ancona; Passion of Christ; Saint Lawrence; Vision of Afterlife, Perugia.

Название статьи. Фрески в Сан-Лоренцо-аль-Лаго в Фиастре и «Sermo Rusticus» в живописи Южной Марке.

Сведения об авторе. Д’Аттаназио Марко - Ph. D. Университет Г. Д’Аннунцио Кьети-Пескара, ул. Деи Вестини, 31, Кьети, Италия, 66100. marco.dattanasio@gmail.com

Аннотация. Церковь Сан-Лоренцо-аль-Лаго в деревушке Фиастра близ Камерино украшена интересным циклом росписей, представляющим сцены страстей Христовых, мученичество св. Лаврентия и образы райского блаженства - три праотца с душами. Эти росписи можно датировать 1275 г. по надписи.

Иконография отличается значительным своеобразием: сцены жизни Христа сопоставлены со сценами жизни св. Лаврентия - святого, которому посвящена церковь. С точки зрения стилистики, представляющей еще больший интерес, можно отметить чрезвычайную простоту линий и колорита, который сводится к белому, черному, желтому и красному цветам.

До сих пор эти фрески оставались вне поля зрения исследователей. В статье предложен их анализ, выдвинуто мнение, что они являются важным примером живописи «sermo rusticus» в Марке. Термин «Sermo rusticus» был введен Пьетро Скарпеллини применительно к памятникам Перуджи и ее окрестностей. Исследователь называл так художественную манеру, которой свойственна исключительная простота.

Росписи Сан-Лоренцо-аль-Лаго в действительности имеют самое очевидное сходство в стилистике именно с церквями Перуджи - Сан-Бевиньяте, Санта-Мария-ди-Анчелле и Сан-Джованни-дель-Фоссо. Что еще более важно, возможно, они послужили источником вдохновения для создателей фрагментарно сохранившихся фресок церквей в Асколи Пичено - Сан-Джакомо (святые и Мадонна Млекопитательница) и Сан-Витторе («Положение во гроб»).

Таким образом, представляется возможным утверждать, что стиль «sermo rusticus» был распространен не только в Умбрии, но и в Марке, вплоть до Адриатического побережья. Это, несомненно, обогащает представления о разнообразии стилей в регионе, каким он был в границах конца XIII в.

Ключевые слова: Сан-Лоренцо-аль-Лаго; Фиастра; Асколи Пичено; sermo rusticus; фрески; Южная Марка; Анкона; Страсти Христовы; Святой Лаврентий; образы посмертной жизни; Перуджа. 


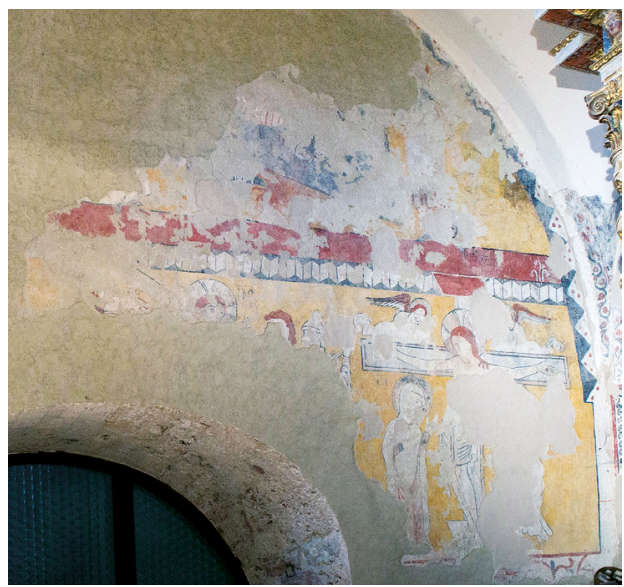

Ill. 80. Christ carrying the cross; Crucifixion; Martyrdom of St. Lawrence. 1275. San Lorenzo al Lago, Fiastra

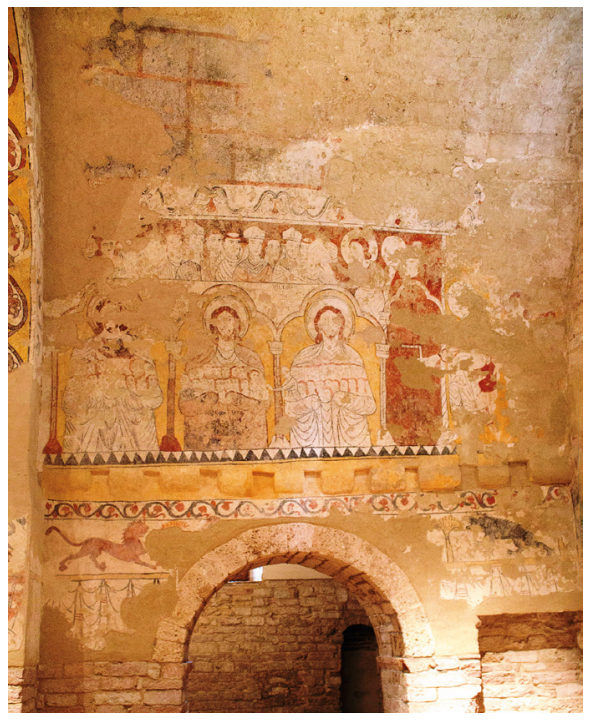

Ill. 81. Vision of the Afterlife. 1275. San Lorenzo al Lago, Fiastra

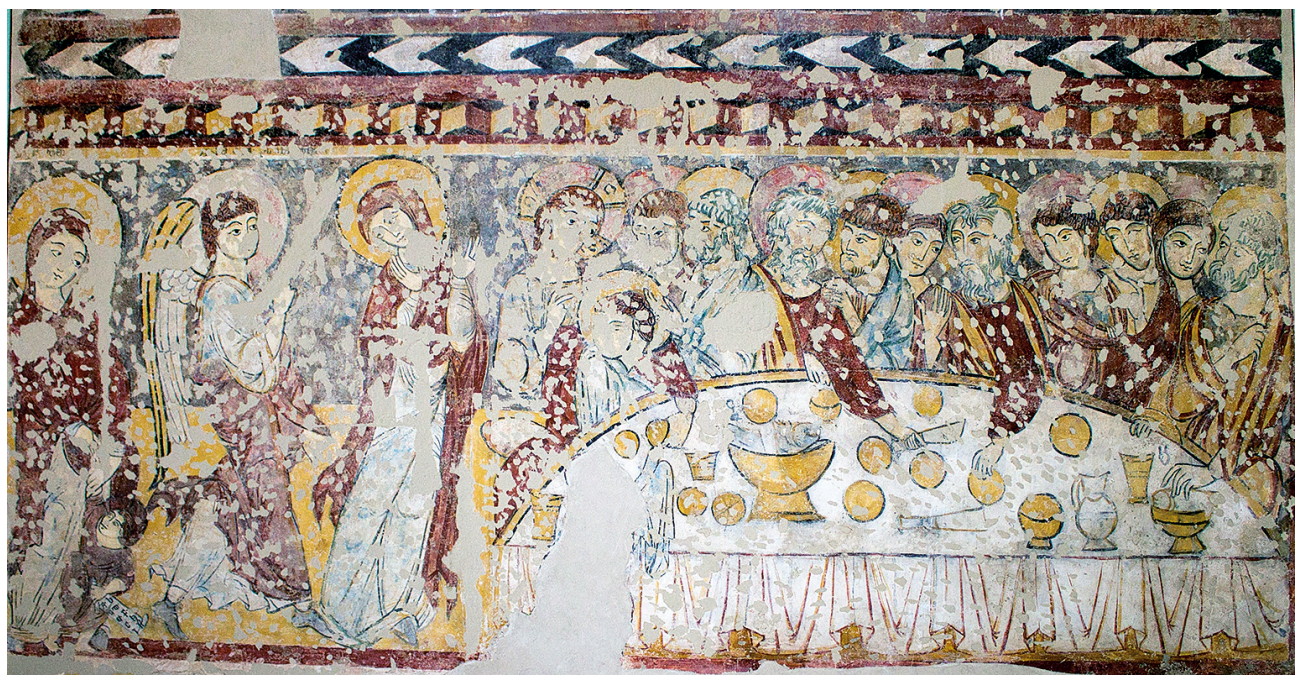

Ill. 82. The Virgin leading Christ to school; Annunciation; Last Supper. Ca. 1280-1290, Episcopal palace, Ascoli Piceno (from the church of San Vittore, Ascoli Piceno) 